\title{
Pongamia pinnata $L$. (Karanja) based agri-silviculture system under rainfed conditions of south-west Haryana
}

\author{
N. Kaushik", R.P.S. Deswal, Abha Tikkoo, Sushil Kumari ${ }^{1}$, Suman Malik and Krishan \\ Kumar
}

Regional Research Station, Bawal, Rewari-123 501 (Haryana), INDIA

${ }^{1}$ Department of Forestry, CCS Haryana Agricultural University, Hisar-125 004 (Haryana), INDIA

*Corresponding author. E-mail:nk20025@rediffmail.com

Received: February 3, 2015; Revised received: May 2, 2015; Accepted: January 14, 2016

\begin{abstract}
The present study was conducted to assess the the performance of Karanja based agri-silviculture system in rainfed conditions of south west Haryana. The results showed that the yield (grain and fodder) of different crops was not affected significantly by the Karanja trees during initial four years of plantation. The mean grain yield of crops viz. cowpea $(9.47 \mathrm{q} / \mathrm{ha})$, cluster bean $(9.13 \mathrm{q} / \mathrm{ha})$, dhaincha $(8.57 \mathrm{q} / \mathrm{ha})$ and mung bean $(9.50 \mathrm{q} / \mathrm{ha})$ was slightly less in agri-silvicultue system as compared to sole cropping. Similar trend was also observed for fodder yield. Karanja growth (height and diameter) was more in agri-silviculture as compared to sole plantation. Maximum height of $300.00 \mathrm{~cm}$ and diameter of $89.20 \mathrm{~mm}$ was recorded when Karanja was intercropped with cowpea, whereas it was $281.20 \mathrm{~cm}$ (height) and $80.90 \mathrm{~mm}$ (diameter) in sole plantation. Agri-silviculture system also improved the organic carbon and available $\mathrm{N}, \mathrm{P}, \mathrm{K}$ as compared to sole cropping. The lower net returns from agri-silviculture system of Karanja + cowpea (Rs. 7178/ha), Karanja +clusterbean (Rs. 7725/ha), Karanja +dhaincha (Rs. 7254/ha) and Karanja + mung bean (Rs. 7100/ha) were mainly due to the fact that during initial years Karanja plantation required some cost without any economic return. It is evident from the results that the cost of establishment of plantation can be meet out through intercropping during the gestation period of Karanja plantation.
\end{abstract}

Keywords: Agri-silviculture, Growth, Karanja, Pongamia pinnata, Yield

\section{INTRODUCTION}

Agroforestry plays an important role in the economy of arid and semi-arid regions due to high risk involved with arable farming, which is affected by low and highly variable rainfall, low soil fertility and high wind velocity. The farmers grow scattered trees and shrubs in their agriculture fields or grazing fields to sustain their life. The trees provide fuelwood, fodder, fruit, vegetable, timber and fiber for sustaining farmers' livelihood. Besides these, agroforestry is capable of conserving natural resources under different agro-climatic regions and is the only option to increase the forest/tree cover from present $(<25)$ to 33 percent in the country. The example of two Indian states i.e. Haryana and Kerala seems fit. With merely 3.5 percent of Haryana's area under forests, the state has become self-sufficient in small wood, fuel wood and industrial timber by establishing large-scale plantations under agroforestry (Ahmed, 2008). Similarly, the case of Kerala suggests that the state has a surplus of 0.027 million $\mathrm{m}^{3}$ of wood in terms of consumption, while the total wood production in the state is 11.714 million $\mathrm{m}^{3}$, the forests provide only about 10 per cent whereas, trees in home gardens and mixed cropping multi-tier agroforestry system contribute to the remaining 90 percent (Krishnankutty et al., 2008). In general, farmers are not interested to grow Karanja in the agricultural fields because of small land holdings and no income during the initial years of establishment. But agri-silviculture (agroforestry) can accommodate both the trees and arable crops. Intercropping, especially during the tree gestation period, could be economically profitable and is environmentally sound indeed, given the prevalent hostile environmental conditions in arid and semi-arid regions. Recently, India has announced the National Agroforestry Policy, 2014, advocating the growing of trees on farms to meet a wide range of products such as fodder, fuel and timber.

Pongamia pinnata (L.) commonly known as Karanja is an important non-edible tree borne oil seed crop that grows in semi-arid regions. The oil has been treated as fuel in diesel engine showing good thermal efficiency. Oil is also used as a fuel for cooking and burning of lamps, as a lubricant, water paint binder, pesticides and tanning industries (Burkill, 1966). It bears 15 to $90 \mathrm{~kg}$ seeds per tree which contains about 15-40 per cent oil. It can be cultivated on marginal lands and has the potential to not only provide renewable energy resource but in addition will alleviate the competitive situation that exists with the food crops as biofuels and associate arable land and water use. It is native to 
Indian sub-continent. Therefore, the present study was conducted to assess the performance of Karanja based agri-silviculture system in semi arid conditions of Haryana, India.

\section{MATERIALS AND METHODS}

Study area: The field experiment was conducted from 2007-08 to 2009-10 at Chaudhary Charan Singh Haryana Agricultural University Regional Research Station, Bawal (Haryana), India located in south west Haryana $\left(28.1^{\circ} \mathrm{N}, 76.5^{\circ} \mathrm{E}\right.$ and $266 \mathrm{~m}$ above mean sea level). The site is characterized by erratic and inadequate precipitation $(300-550 \mathrm{~mm})$ only during monsoon season (July - September). During experimentation period, the maximum temperature was reached as high as $46^{\circ} \mathrm{C}$ whereas, the average minimum temperature was recorded around $2^{\circ} \mathrm{C}$ during peak winter months of December and January. Between October and March, weather was almost dry except occasional light showers. Thereafter, it was quite dry till June. The soil of the experimental site was sandy loam in texture, low in organic carbon $(0.22 \%)$ and avialble $\mathrm{N}(96.0 \mathrm{~kg} / \mathrm{ha})$ medium in available phosphorus $(12.0 \mathrm{~kg} / \mathrm{ha})$ and available potassium (177.0 kg / ha). The $\mathrm{pH}(1: 2)$ of experimental field was 8.41 and EC (1:2) $0.30 \mathrm{dSm}^{-1}$.

Plantation and treatments: Eight months old seedlings were transplanted in field during March, 2006 in pits of $45 \mathrm{~cm}^{3}$ at a spacing of $6 \times 6 \mathrm{~m}$ with three replications by laying the plots in randomized block design. The plants were raised following agro-techniques recommended for the region. Weeding and cleaning in plant basin was undertaken as and when required. The cultivation of crops in the interspaces of plants was started after one year of planting. Cowpea (Vigna unguiculata (L.) Walp), cluster bean (Cyamopsis tetragonoloba L.) Taub) and dhaincha (Sesbania aculeata) were grown separately

Table 1. Grain yield (q/ha) of different crops under agri-silviculture and sole cropping.

\begin{tabular}{|c|c|c|c|c|}
\hline \multirow{2}{*}{ Crop } & \multicolumn{3}{|c|}{ Yield (q/ha) } & \multirow{2}{*}{ Mean } \\
\hline & 2007-08 & 2008-09 & 2009-10 & \\
\hline \multicolumn{5}{|c|}{ With Karanja (agri-silviculture) } \\
\hline Cowpea & 10.90 & 8.90 & 8.50 & 9.47 \\
\hline Cluster bean & 10.00 & 9.00 & 8.00 & 9.13 \\
\hline Dhaincha & 9.50 & 10.00 & 8.20 & 8.57 \\
\hline Mung bean & 10.00 & 9.50 & 9.00 & 9.50 \\
\hline \multicolumn{5}{|l|}{ Sole } \\
\hline Cowpea & 11.00 & 9.00 & 10.00 & 10.00 \\
\hline Cluster bean & 11.00 & 9.00 & 9.00 & 9.70 \\
\hline Dhaincha & 9.50 & 11.00 & 10.50 & 10.33 \\
\hline Mung bean & 10.50 & 9.50 & 9.90 & 10.00 \\
\hline $\mathrm{CD}(5 \%)$ & NS & NS & NS & \\
\hline
\end{tabular}

Table 2. Fodder yield (q/ha) of different crops under agri-silviculture and sole cropping.

\begin{tabular}{lcccc}
\hline \multirow{2}{*}{ Crop } & \multicolumn{3}{c}{ Yield (q/ha) } & \multirow{2}{*}{ Mean } \\
\cline { 2 - 4 } & $\mathbf{2 0 0 7 - 0 8}$ & $\mathbf{2 0 0 8 - 0 9}$ & $\mathbf{2 0 0 9 - 1 0}$ & \\
\hline With Karanja (agri-silviculture) & & & & 177.50 \\
\hline Cowpea & 186.00 & 176.50 & 152.00 & 161.67 \\
Cluster bean & 163.00 & 170.00 & 250.00 & 253.33 \\
Dhaincha & 265.00 & 251.00 & 181.00 & 181.67 \\
\hline Sole & & & 160.00 & 167.00 \\
\hline Cowpea & 190.00 & 180.00 & 258.50 & 262.83 \\
Cluster bean & 168.00 & 173.00 & $\mathrm{NS}$ \\
Dhaincha & 270.00 & 260.00 & & \\
CD $(5 \%)$ & $\mathrm{NS}$ & $\mathrm{NS}$ & & \\
\hline
\end{tabular}

Table 3. Growth of Karanja under agri-silviculture and sole cropping.

\begin{tabular}{lcccccc}
\hline \multirow{2}{*}{ Crops } & \multicolumn{3}{c}{ Height (cm) } & \multicolumn{3}{c}{ Diameter (mm) } \\
\cline { 2 - 7 } & $\mathbf{2 0 0 7 - 0 8}$ & $\mathbf{2 0 0 8 - 0 9}$ & $\mathbf{2 0 0 9 - 1 0}$ & $\mathbf{2 0 0 7 - 0 8}$ & $\mathbf{2 0 0 8 - 0 9}$ & $\mathbf{2 0 0 9 - 1 0}$ \\
\hline Cowpea & 101.11 & 186.50 & 300.00 & 20.17 & 31.78 & 89.2 \\
Cluster bean & 103.80 & 190.20 & 293.50 & 18.92 & 32.00 & 85.8 \\
Dhaincha & 102.11 & 196.50 & 295.00 & 19.33 & 30.73 & 87.8 \\
Mung bean & 104.00 & 192.00 & 290.00 & 20.42 & 31.78 & 84.8 \\
Sole & 100.50 & 198.50 & 281.20 & 19.00 & 29.33 & 80.9 \\
\hline CD $(5 \%)$ & NS & 9.2 & 12.7 & NS & 0.90 & 1.80 \\
\hline
\end{tabular}


Table 4. Soil properties ( $0-30 \mathrm{~cm}$ depth) at start and after 3 years under agri-silviculture and sole cropping.

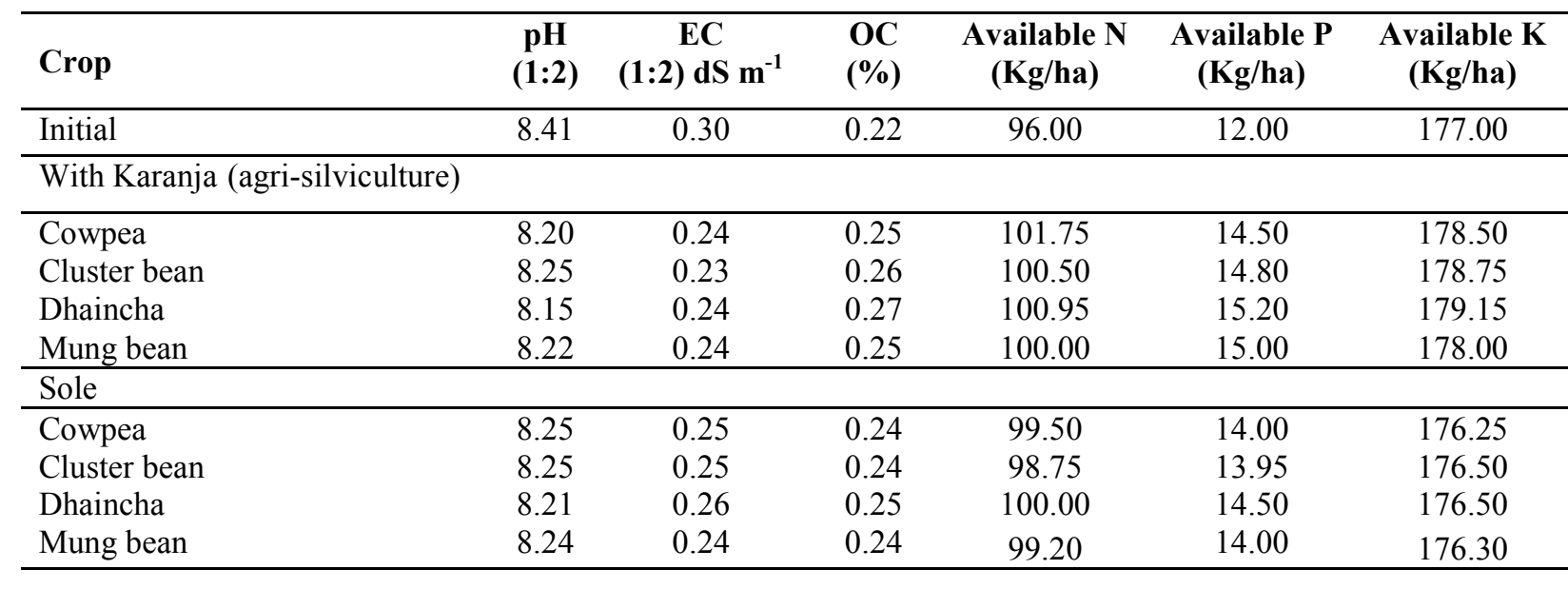

for grain and fodder whereas mung bean (Vigna radiata (L) R. Wilczek) was raised only for grain purpose. The experiment was repeated for the next two years with same treatments. The crops were raised as per recommended cultural practices of the region. During the period of experimentation, the crops were raised under rainfed conditions. The soil samples were collected at the beginning (initial) and at the end of the experiment from $0-30 \mathrm{~cm}$ depth. The soil samples were air dried and brought to the laboratory and crushed with mallet and sieved 20 mesh for analysis. The soil $\mathrm{pH}$ was estimated using glass electrode $\mathrm{pH}$ meter method and electrical conductivity (EC) was determined by conductivity meter (Jackson, 1973). Organic carbon (\%) was measured by Walkley and Black's rapid titration method (Walkley and Black 1934). Available nitrogen, phosphorus and potassium were estimated by using Kjheldhal's method (Jackson, 1973), Olsen's method (Olsen et al., 1954) and flame photometer method (Jackson 1973), respectively. For economic evaluation of the system, the cost items included the cost of plants, labour charges for digging pits, planting and training of trees, charges for ploughing the field for field prepartion and for cultivation of crops, material inputs such as seed and fertilizer, labour cost for different field operations, harvesting and threshing charges of crops, interest on working capital and rental value of land was calculated on the basis of prevailing market prices in nearby villages. For calculating returns prevailing market rates of grain and straw of the intercrops were taken as the saling costs.

\section{RESULTS AND DISCUSSION}

Yield of intercrops: Grain and fodder yield of arable crops raised in the interspaces of Karanja was less as compared to their sole cropping during the period of experimentation, but the differences were nonsignificant (Table 1,2). The mean grain yield of crops viz. cowpea $(9.47 \mathrm{q} / \mathrm{ha})$, cluster bean $(9.13 \mathrm{q} / \mathrm{ha})$, dhaincha $(8.57 \mathrm{q} / \mathrm{ha})$ and mung bean $(9.50 \mathrm{q} / \mathrm{ha})$ was slightly less in agri-silvicultue system as copmared to sole cropping. The maen fodder yield was maximum in dhaincha as sole crop $(262.63 \mathrm{q} / \mathrm{ha})$ as well as intercrop $(253.33 \mathrm{q} / \mathrm{ha})$ followed by cowpea and cluster bean. Maximum fodder yield of $270.00 \mathrm{q} /$ ha was recorded in sole dhaincha during the $1^{\text {st }}$ year. The yield was slightly less during the third year $\left(4^{\text {th }}\right.$ year of plantation), may be due to crown spread of trees. During the first four years, the yield of the crops were almost identical with Karanja and control. This might be due to less crown area and more interception of light by trees in the initial years. The result is in conformity with Nandal and Kumar (2010) who had reported that green matter yield of dhaincha, grain yield of wheat and barley and fodder yield of berseem remained unaffected when grown in the interspace of Melia azedarach during the first four years of plantation. In our earlier studies (Kaushik et al., 2011 and 2014) it was observed that different silvi-horti systems namely, Shisham (Dalbergia sissoo) + Aonla (Embilica officinalis), Shisham (D. sissoo) + Guava (Psidium guajava), Khejri (Prosopis cineraria) + Aonla (E. officinalis) and Khejri (P. cineraria) + Guava (P. guajava) did not affect the yield of intercrops significantly during intial four years of plantation. Similar results have also been reported in our present study.

Growth performance of Karanja tree under sole and agri-silviculture system: Karanja growth (height and diameter) increased gradually with increasing age

Table 5. Economic returns of different crops under karanja tree (mean of 3 years).

\begin{tabular}{lcc}
\hline $\begin{array}{l}\text { With Karanja (agri- } \\
\text { silviculture) }\end{array}$ & $\begin{array}{c}\text { Gross returns } \\
\text { (Rs/ha) }\end{array}$ & $\begin{array}{c}\text { Net returns } \\
\text { (Rs/ha) }\end{array}$ \\
\hline Cowpea & 21728 & 7178 \\
Cluster bean & 22125 & 7725 \\
Dhaincha & 21854 & 7254 \\
Mung bean & 21800 & 7100 \\
\hline Sole & \\
\hline Cowpea & 22000 & 13150 \\
Cluster bean & 22610 & 13910 \\
Dhaincha & 21926 & 13026 \\
Mung bean & 22100 & 13100 \\
\hline
\end{tabular}


(Table 3). The intercropping of different crops affected the Karanja growth positively and significantly $(\mathrm{P}>0.05)$, however it was non-significant during the first year. Karanja growth (Height and diameter) was more in agri-silviculture as compared to sole plantation. Maximum height $(300.00 \mathrm{~cm})$ and diameter $(89.2$ $\mathrm{mm}$ ) was recorded when Karanja was intercropped with cowpea during third year of study. Minimum growth was recorded in sole plantation. More growth of Karanja in agri-silviculture than sole plantation of Karanja might be attributed to benefit of crop management practices like field preparation, fertilizer application and addition of nitrogen through nitrogen fixatation by all the crops being legumineous. Nandal and Kumar (2010) also reported more growth (height and girth) in Melia azedarach grown with dhaincha, wheat, barley and berseem as compared to sole cropping.

Status of the soil: A marked fall in $\mathrm{pH}$ and EC was observed in agri-silviculture system as compared to sole cropping (Table 4). Maximum decrease was recorded in dhaincha + Karanja system. Reduction in salt concentration under agri-silviculture system might have been mediated by decomposition of tree and crop litter. Agri-silviculture system improved the organic carbon and available N, P, K as compared to area without trees. This was due to increased biological activity through crop and trees, litter fall, $\mathrm{N}$ fixation and applicaion of N, P, K through fertilizers. Soil microbial biomass and enzyme activities increased under different Multipupose Tree Species (MPTs) based agroforestry land uses as compared to sole cropping (Yadav et al., 2011). Increased soil fertility status under trees over control have also been reported by Pandey et al. (2011) and Banerjee and Dhara (2010).

Economics of the system: The gross as well as net returns of all the crops were higher under sole cropping than agri-silvicultue system (Table 5). Maximum return (Rs. 13910/ha) were received from clusterbean sole cropping. The lower net returns from agrisilviculture system was mainly due to the fact that during initial years Karanja plantation required some cost without any economic return. But it is evident that the cost of establishment of plantation can be meet out through intercropping during the gestation period of plantation. Higher net returns from Melia + dhainchaberseem crop rotation have also been reported by Nandal and Kumar (2010) and in similar way Kaushik et al., 2011(a) reported that yield of different crops was not affected by different tree combinations during initial two years.

\section{Conclusion}

Grain and fodder yield of arable crops raised in the interspaces of Karanja was not affected by the Karanja plantation during intial four years of plantation. Agri-silviculture system improved the organic carbon and available $\mathrm{N}, \mathrm{P}, \mathrm{K}$ as compared to sole cropping. It is evident from the results that the cost of establishment of plantation can be meet out through intercropping during the gestation period of Karanja plantation.

\section{REFERENCES}

Ahmed, P. (2008). Trees outside forests (TOF): A case study of wood production and consumption in Haryana. International Forestry Review, 10(2): 165-172.

Banerjee, H. and Dhara, P.K. (2010). Sustainability and profitability of different agri-horti- silviculture systems in rainfed agro-ecosystem. Indian Journal of Aroforestry, 12(2): 79-85.

Burkill, J.H. (1966). A dictionary of economic products of Malay peninsula L. Art Printing Works, Kuala Lumpur.

Jackson, M.L. (1973). Soil chemical analysis. Prentice Hall of India Pvt. Ltd., New Delhi.

Kaushik, N., Sushil Kumari, Surender Singh and Kaushik J.C. (2014). Productivity and economics of different agri-silvi-horti systems under drip irrigation. Indian Journal of Agricultural Sciences, 84 (10): $1166-71$.

Kaushik, N., Kaushik, R A., Kumar, Sushil, Sharma, K. D. and Dhankhar, O. P. (2011). Comparative performance of some agri-silvi-horti systems with drip irrigation under arid regions. Indian Journal of Horticulture, 68 (1): $12-17$.

Kaushik, N., Krishan Kumar, Sushil Kumar, R.P.S. Deswal and Deswal A. K. (2011a). Performance of Jatropha (Jatropha curcas L.) based agroforestry system under rainfed conditions. Indian Journal of Agroforestry, 13 (1): $100-102$.

Krishnankutty, C.N., K.B. Thampi and Chundamannil, M. (2008). Trees outside forests (TOF): A case study of the wood production-consumption situation in Kerala. International Forestry Review, 10 (2): 156-164.

Nandal, D.P. S. and Kumar, Ravi (2010). Influence of Melia azedarach based land use systems on economics and reclamation of salt affected soil. Indian Journal of Agroforestry, 12(1): 23-26.

Olsen, S.R., C.V. Cole, F.S. Watanake and Dean, C.A. (1954). Estimation of available P in soil by extraction with sodium bicarbonate: Circ US.Dept Agric 939.

Pandey, A. K., V. K. Gupta, and Solanki, K.R. (2011). Performance of gram (Cicer arietinum) under neem based agroforestry system in semi-arid region. Indian Journal of Agroforestry, 13 (1): 61-66.

Walkley, A. and Black, T. A. (1934). An examination of degtzariff method for determining soil organic matter and proposed modification of the chromic acid titration method. Soil Science, 37: 29-39.

Yadav, R. S., B. L. Yadav, B. R. Chhipa and Dhyani, S. K. (2011). Soil biological properties under different tree based traditional agroforestry systems in a semi-arid region of Rajasthan, India. Agroforestry Systems, 81:195-202. 